\title{
Social Obligations of the State in Ensuring Economic Security of Russia
}

\author{
Gryaznova E.V.* \\ Doctor of Philosophy, Professor, Head of the Department of \\ Philosophy and Theology \\ Minin Nizhny Novgorod State Pedagogical University \\ Nizhny Novgorod, Russia \\ e-mail: egik37@yandex.ru
}

Treushnikov I.A.

Doctor of Philosophy, Professor of the Department of Humanitarian and Socio-Economic Disciplines

Russian State University of Justice (Privolzhsky Branch);

Professor, Head of the Department for Philosophy

Academy of the Ministry of Internal Affairs

Nizhny Novgorod, Russia

e-mail: treushnikovilya@mail.ru

\section{Vladimirov A.A.}

Doctor of Philosophy, Professor, Head of the Department of Philosophy and Social Sciences

Volga State University of Water Transport

Nizhny Novgorod, Russia

E-mail: nruch@vgavt-nn.ru

\author{
Goncharuk A.G. \\ Candidate for Philosophical Sciences, Senior Lecturer \\ Of the Department of Philosophy and Theology; \\ Minin Nizhny Novgorod State Pedagogical University \\ Nizhny Novgorod, Russia \\ e-mail: aleksgon75@gmail.com \\ Pronina S.V. \\ Candidate for Economic Sciences, Assistant Professor \\ of the Department of Management and Public \\ Administration \\ Lobachevsky State University of Nizhny Novgorod \\ Nizhny Novgorod, Russia \\ e-mail: proswet5@yandex.ru
}

Krygin S.V.

Candidate of Juridical Sciences, Docent of the Department of Humanitarian and Socio-Economic Disciplines

Russian State University of Justice (Privolzhsky Branch);

Deputy Head of the Department of mathematics,

Informatics and information technologies

Academy of the Ministry of Internal Affairs

Nizhny Novgorod, Russia

e-mail:kryginsv@mail.ru

Keywords - anthropology of economic security, social obligations of the state, globalization, information economy, information society

\section{INTRODUCTION}

The problem of security is the subject of research for specialists in various fields of knowledge. For example:

- in the field of security of informatization and virtualization of the social space [7];

- in the framework of the historical aspects of ensuring state security of the country [5];

- in the relationship of environmental and economic security [12], problems of psychological and social security [17];

- in ensuring the safety of the educational space and cultural development of a person $[6,14,18]$;

- in the field of management and the organizational mechanism for the effective provision of Russian entrepreneurship [11] etc.

We believe that the attempt to philosophically substantiate this problem, as well as the attempt to analyze various aspects 
of the problem of ensuring the economic security of Russia $[3,13,15]$ is not without its cognitive meaning and significance.

The desire to consider the causes of economic crime systematically, considering many aspects of this problem, undoubtedly deserves serious attention. Legal regulation of economic processes and the efforts against crimes in the economic sphere should take into account the relationship of economic processes with other (social, political, psychological, ideological, geopolitical etc.) systems of relations. This relationship in the present period is so obvious that the attempt to consider them in isolation seems to be very naive. Modern researchers must think systematically, one way or another, moving to different levels of generalization, embedding economic reality in other forms of being. In this text we will not strictly differentiate between economic and economic activity despite the fact that attempts to distinguish them are made, in particular, within the framework of a special branch of knowledge - the philosophy of economy [4].

In this regard, we believe that the possibility of a philosophical understanding of the functioning of the system of combating economic crime should not be ignored. At the philosophical level, we can talk, first of all, about the general principles from which we should proceed when deciding on issues related to the economic security of the state, society and man.

\section{RESEARCH METHODOLOGY}

The methodological basis of the analysis will be the concept of the social state, developed by Professor L.A. Zelenov. When analyzing social life, Zelenov highlighted eight main areas of society, which allows a more detailed analysis of the functioning of the social organism [20], as well as methods of analysis, comparison, generalization and the principles of dialectics.

\section{RESULTS AND DISCUSSION}

Studying the problem of national security of Russia in the context of economic philosophy, we concluded that this problem has a pronounced anthropological aspect. At the center of the social system is a person with his interests, abilities and the entire spiritual and cultural structure [1].

One way or another, the problem of ensuring economic security should be locked on the human person. Although it should be recognized that most researchers pays primary attention to institutionalized prolongations of human existence, expressed primarily in social and economic systems. One of the most significant elements of these systems, of course, is statehood which is most often presented by researchers as the most visible manifestation of national interest [10].

Nevertheless, we believe that the analysis of the economic aspect of security, its provision in various forms, does not lose its relevance and cognitive significance [8]. In this paper, we will consider the state as an active agent of society, as a complex object of all social activity, which is the basis of human culture. This is precisely about society, and not about classes, strata, parties, groups, workers, peasants, entrepreneurs, etc., because the state was born of society and its contradictions, and should be responsible to the whole society. This is an important starting point.

In this regard, it is necessary to consider the social obligations of the state, caused not by its subjective regulations in the form of the Constitution or legal laws, because they, which is possible, are created in the interests of a certain class, but due to the objective status of the state as a social institution of a society that is not regulated, but determined by the cultural and historical logic of the development of society [2].

This can immediately raise objections, justified by references to the Constitution, in which obligations, including social ones, are written down: to take care of pensioners, women and children, military and office workers, disabled persons, etc.

But obligations presuppose the implementation by the state of quite definite "social activities", which will testify not to possible, potential, but to the actual functions of the state. And it is precisely these real social activities of the state that lead to real, not fictitious, social conflicts that need special analysis. Adequate implementation of social activities by the state will, in our opinion, make it possible to ensure economic security, both of the state itself and of society and the individual.

Consider the basic social obligations of the state arising from its essence and nature. By focusing on the social responsibilities of the state you can find that the objective reasons (determination) of the responsibilities of the state follow, firstly, from the objective needs of the state (classes and private property) and secondly, from an objective entity that reveals its nature (order, submission and violence).

Such a statement will free us from the widespread, but more often not confirmed by historical practice thoughts about the peacekeeping, universal-humane duty of the state. No matter how people, nations, afflicted, impoverished, needy, etc. want to see the Father, Protector, Benefactor, Kind Uncle, Universal Philanthropist in the state - objectively the state has not played this universally noble role and cannot play because it is class in its character and not national [19].

We must not forget that the duties of the state are determined by its essence. This idea can be reflected in the following points:

1. The state is obliged to protect the class of proprietors from attacks on it by external and internal enemies.

2. The state is obliged to legally execute and protect the private property of native and foreign citizens.

3. The state is obliged to establish the order of life and civil relations in the system of society.

4. The state is obliged to subordinate citizens to normative regulations by the method of legal coercion.

5. The state is obliged to carry out violence against citizens who violate the legal norms of the existence of society.

These basic obligations of the state are transformed into its rights: the rights to protect, subjugate, enforce, establish, etc. within the boundaries of the positive-legal powers of state 
bodies. Everything else is voluntary (charity) or forced (reforms) possible (potential) functions of the state: it can carry them out or not (raise pensions, lower prices, raise taxes, housing, road construction, free education, contracting, etc.) Such an interpretation seems very rigid and unambiguous, but we proceed from the generic, specific nature of the state, which was formed historically on a class basis.

Social obligations of the state determine the goals of its social activities. The certain peculiarity of this activity is that it is carried out by the functional organs of the state and the state itself, in the form of three branches of its power, manages these activities. We consider the main directions of the state's activity through the prism of the country's economic security, using the methodology of the spheres of public life in society. This will make it possible to comprehend the extent to which the social obligations of the state are really being realized, including the obligation to ensure economic security of which the person is the final addressee. We will deliberately take a critical position starting from the most noticeable examples for us.

We face a number of issues in the economic sphere of society. Is the state called to govern the economic sphere of society? Current trends in the development of the state, focused on the installation of liberal ideology, declare the gradual withdrawal of the state from the economic sphere [9].

This is due to at least two circumstances: a) the concentration of national ownership in the hands of the class of private owners (oligarchs), and not in the hands of the state. In the post-Soviet period it voluntarily privatizes and sells "its" state property to private capital by privatization methods and b) hoping that the "invisible hand of the market" will be able to regulate the economic sphere, therefore the state should not manage it.

We see all this in explicit form on the example of the formation of the bourgeois state and the bourgeois economy in Russia since 1992. Entrepreneurs and businessmen rejoice in the freedom of economic activity (produce what you want, sell to anyone you want, how much you want, pay any salary, etc.). What remains to the state? In the economic sphere: tax collection, property transactions, interest rates, privatization, printing of money, creation of a stabilization fund, creation of a gold and foreign exchange reserve, spending of the state budget, partial payment of pensions and some allowances, partial (mainly defense) orders. As we see, all economic activities are financial in nature. The state does not produce, does not distribute, does not exchange, but partially only consumes contracted products. There are also customs duties, but this is also a financial operation.

Thus, the basic economic functions are not fully embodied by the state. All "economic" operations are virtual, because they are made with money, with the financial potential of the country: money production, money distribution, money exchange, money consumption. This is a "virtual economy." The presence of the state in the basic commodity areas of the economy (oil and gas) is explained by their quick, low-cost and abundant returns. But both the proposal and the demand to remove the state from the "raw material needle" have already matured in society. Our state is moving away from a rawmaterial economy into a production one very slowly: the risk is great in moving from money to goods, from it to the production of new goods and their transformation into added money $(\mathrm{M}-\mathrm{G}-\mathrm{P}-\mathrm{G}-\mathrm{M})$. The conclusion suggests itself: our state is not an entrepreneur, but a businessman, because risky activity is the main feature of entrepreneurs of all kinds.

Will the state return to the economy? Apparently not, because it is liberal-capitalist: it leaves production, from distribution, from exchange and from consumption, i.e. from real economic activity. This is evidenced by critics of the postSoviet model of economic development. They regretfully emphasized: if the management functions are overturned in the economic sphere, then we can see that there is no state planning. The state has abandoned its five-year plans, and today's "programs" are operational not binding, and abstract. The pseudo-democrats and liberals unreasonably and negatively derided the five-year planning periods and the State Planning Committee itself. But we taught to plan the USA, England, France, Italy, Germany, Japan. They created their own National Planning Committees following the Soviet model!

There is no organization function since enterprises are owned by private owners, a labor market has been created, the real estate market as well as the goods market, i.e. spontaneous "market economy": it is impossible to organize personnel, objects, means, processes, results, environment in relation to the economic sphere. And it is not necessary! - say the liberals. - The market organizes everything by itself. But why did economic crises become regular then, generated by financial crises, and even every 10 years $(1998,2008)$ ? This regularity was predicted and justified by $\mathrm{K}$. Marx and V.1. Lenin in the 19th century: private property capitalism cannot develop without crises, because with all the organization within the company on a state scale, it is chaos. We may also call the capitalism "people's" soon, as once in Europe did, but the essence remains.

The leadership function is also absent, because there is nothing to lead, no one to give instructions, make management decisions. The state only asks businessmen to help create Skolkovo, to finance the work of budget universities, to create a funded part of the pension, to repair Arkhangelskoye, to build a kindergarten, to start a factory, to ensure mine safety, to build a church, etc. Business just smirks and transfers money to foreign banks!

The control function which assumes the feedback of the subject with the object is absent in the form of accounting, reporting, because there is no one for and no one to report to. Ministers are summoned to the State Duma, but ministers do not manage factories, factories, mines, universities, hospitals, kindergartens. And the governors and mayors are helpless, because private owners are functioning on their territories. It remains only to recall articles of The Labor Code or The Constitution which prohibit a 12-hour working day or a 6-day working week. But businessmen themselves and their managers work 16 hours a day!

If there is no control function - then the regulatory function is also not needed, that is to make adjustments, amendments, changes to previous management functions and to economic activity itself. Even mistakes do not need to be 
recognized, because they cannot exist in the absence of a planning function!

Here are a number of statistics showing the development in state economic sphere in our country. For example, in the world ranking in terms of "population health" in 2016 Russia was among 117-119 places [16]. In a similar ranking in terms of education, Russia occupies only 36th line. If we take into account that in the Soviet times our country was in the top three world leaders by this criterion, then these indicators show a sharp decline in one of the most important indicators of human capital development [16]. In terms of "spending on science in shares of GDP" Russia occupies only 32nd place [16]. These indicators determine, first of all, the level and quality of the country's human capital. As you know, the loss of this capital leads to a decrease in the economic competitiveness of the state. Nevertheless, spending on national security brings our country closer to world leaders [16]. If we take into account that the increase in these expenses is connected, first of all, with the growth of crime and terrorist threats, then Russia should be designated as a "fragile state".

\section{CONCLUSION}

Thus, in general it can be said that the modern state in Russia does not carry out in full and effective strategic and constructive volume all the basic functions of governing the country, in all its basic activities and areas. If something is done, it is done mainly in financial and commercial interests, in the interests of profit and income, i.e. the state itself acts as a big businessman (not even an entrepreneur!). All this proves the class, private-ownership nature of the state, and its essential quality is reduced not to the management of spheres, but to submission and violence not only in information, but also in physical (power) form. In this regard, we have to admit that ensuring economic security as a "duty" of the state is not sufficiently complemented by its "activities", which obliges us to look for ways and the most effective solutions to the problem of ensuring economic security.

The way out suggests itself - if the nature of the state is unchanged, then society should be transformed in the direction of expanding the class of private owners. Indeed, all the "duties" and "activities" of the state do not make sense on their own, but as a means to realize human qualities. The level of security of each normally socialized person should be such that he can freely realize himself in all eight of the above areas of public life. The expansion of the class of owners, which the state serves, based on its nature to the vast majority will allow resolving the fundamental conflicts mentioned above or, at least, reducing their negative consequences, as long as the contradictions cannot be eliminated. The task of the state, of course, is not to literally enrich every citizen, but to correctly redistribute resources. This idea, if you think about it, goes back to the Aristotelian idea of an ideal society based on the formed majority of free people with property, and a sufficient level of income in order to be able to participate in political life. The "Aristotle model" at this stage seems to be preferable to the "Plato model", implemented in a certain form in socialist countries. Please recall, that the Soviet Union at one time, striving for maximum control of all spheres of public life, was unable to achieve economic security neither of the individual, nor of society, and, ultimately, of the state. The role of the modern social state is to create the necessary conditions for the desired environment.

The question of to what extent in our country the "duties" and "activities" discussed above is fully implemented by the state, and, therefore, the state itself is social, remains debatable. But the question of the true sociality of the state remains open. Is it possible at all, with its class, privateownership nature? Obviously, in order to try to answer this question, it is necessary to continue the research of this phenomenon, having studied the problems of social conflicts, branches of government, governance, etc. in the framework of the attributive concept of the social state, which ultimately will allow us to come closer to the understanding of the social functions of the state as a factor in ensuring economic security. The direction of the social state policy should be determined by its essence. The purpose of such a policy should be a person. This allows us to talk about the possibility of considering the problem of ensuring economic security through the prism of the philosophy of human existence, that is, about the possibility of establishing the anthropology of economic security.

\section{References}

[1] A.V. Babaeva, A.A. Krasheninnikov, "Anthropological dimension of the space of a modern city”, Vestnik of Minin University, Vol. 7, №2, 2019 https://doi.org/10.26795/2307-1281-2019-7-2-14

[2] I.N. Bartsits, Constitutional myths and constitutional illusions: about heroic past and better future. Moscow: Delo Publ., 2018, 57 p.

[3] F. Brunner, Putin's Russia: politics, economics, and U.S. interests. New York: Nova Publ., 2014, 194 p.

[4] S.N. Bulgakov, The philosophy of the economy. Moscow: Instit. of Russ. Civilizat., 2009, 460 p

[5] J. Fedor, Russia and the cult of state security: the chekist tradition, from Lenin to Putin. London; New York: Routledge Publ., 2011, 286 p.

[6] E.V. Gryaznova, I.A. Treushnikov, S.M. Maltseva, "Disturbing trends in the Russian education system: The analysis of scientists and teachers opinions”, Perspektivy Nauki i Obrazovania, Vol. 38, №2, pp. 47-57, 2019.

[7] E.V. Gryaznova, A.A. Vladimirov, S.M. Maltceva, A.G. Goncharuk N.V. Zanozin, "Problems of Virtualization and Internetization of Socia Space", Lecture Notes in Networks and Systems, Vol. 91, pp. 119-124, 2020.

[8] S.S. Khusainova, "Interpretation of the phenomenon of economic security", Azimuth of Scientific Research: Economics and Management”, Vol. 8, iss. 1 № 26, pp. 55-57, 2019.

[9] A.L. Mazin, V.P. Kuznetsov, N.V. Shmeleva, S.S. Kabanov, Z.M Nazarova, "Increasing the Level of Economic Freedom as a Condition of Innovative Development of Russia", Lecture Notes in Network and Systems, Vol. 73, pp. 937-943, 2020.

[10] T.G. Mukhina, N.I. Musina, "Formation of the readiness of a future specialist of the Ministry of Internal Affairs of Russia for interpersonal interaction in a multinational environment", Vestnik of Minin University, Vol. 7, №1, 2019, https://doi.org/10.26795/2307-1281-20197-1-3

[11] T.A. Nesterova, S.V. Pronina, "Supporting the economic security of an enterprise with controlling tools", Economic security of Russia: problems and prospects, pp. 196-200, 2019 [Mater. of the VII Int. Sci. and Pract. Conf.].

[12] "Organization for security and co-operation in Europe", Sixteenth meeting of the Economic and environmental forum: part 1, Vienna, 28-29 January 2008, $41 \mathrm{p}$ 
[13] A.L. Rebane, The new START treaty between the U.S. and Russia, New York: Nova Science Publ., Cop. VIII, 2011, 205 p.

[14] Y.M. Sokolinskaya, E.A. Kolesnichenko, "Criminalization as a main threat to economic security". Proc. of Voronezh State Univer. of Engineer. Technol., Vol. 81, № 1, pp. 480-484, 2019, Retrieved from: https://doi.org/10.20914/2310-1202-2019-1-480-484

[15] "Russia and Northeast Asia: Economic and Security Interdependence", Russ. acad. of sciences. Inst. of world economy \& intern. relations Moscow, Russia, [The Nat. Inst. for Research Advancement], Tokyo, Japan. Moscow: IMEMO, 1999.

[16] Russia in numbers. Krat. stat.sb. Rosstat. Moscow, 2018, 522 p.
[17] R. Stock, Socio-economic security, justice and the psychology of social relationships, Geneva: Intern. labor office, 2001, 73 p.

[18] Y.A. Salikov, V.S. Mikhailiuk, "Methodological approach to the terminological analysis of the key concepts of economic security, Proc. of Voronezh State Univer. of Engineer. Technol., Vol. 81, № 2, pp. 387392, 2019, https://doi.org/10.20914/2310-1202-2019-2-387-392

[19] M.A. Vakhtina, "Violation of social justice in the Russian economy: causes and effects", Karelian Scientific Journal, № 2(11), pp. 66-69, 2015.

[20] L.A. Zelenov, A.A. Vladimirov, L.P. Zagornaya, Attributive theory of the social state, N. Novgorod, 2014, 183 p. 